\title{
The Impact of Oral Corrective Feedback On the Level of Language Anxiety
}

\author{
Zahratul Maujudatul Mufidah \\ State University Of Surabaya \\ Indonesia \\ zahratulmufidah@mhs.unesa.ac.id
}

\begin{abstract}
This study investigated the impact of OCF on the level of LA in learners with low English proficiency by examining whether OCF gives different impact on the learners who have different level of LA. This study is qualitative approach which deals students' psychological situation occurred in natural phenomena through classroom observation by using field note and video recording to gain valid data as well as semi-structured interview is presented to clarify the result and get further information. The findings show that the students from various levels of LA (VA, A, MA \& R) groups claimed OCF helped them to know their mistakes easily and motivate them to study harder but not to increase their speaking performance. This study will give valuable information on how learners' errors and teachers' OCF affect learners' LA level, so the teachers can decide appropriate OCF strategy based on the level of LA. Furthermore, the students can get much more knowledge for better language achievement.
\end{abstract}

Keywords: OCF, Level of LA, English

Proficiency

\section{INTRODUCTION}

Classroom interaction is the fundamental element in teaching and learning process. It occurs in classroom activity between the teacher and the students and points to how the teacher and students interact each other. Classroom interaction cannot be separated with feedback. Feedback as a media to transfer language knowledge into the production of language use in a particular discourse. It defines as one type of interaction that deals to enhance L2 acquisition through constructing self-awareness to the use of language whether it is proper or not, so it will provide the correctness to the learners' error (Saville-Troike, 2006:110). Meanwhile, corrective feedback concerns with only one type of negative feedback. It is used as any response when the learners make linguistic deviant in their utterance. However, corrective feedback given by teacher to the learners may cause language anxiety since the lack of English ability to speak in front of the teacher and classmates too. The research conducted by reference [24] examined that immediate OCF given by the teacher was not effective to increase the fluency and accuracy in speaking. Further, the research by reference [1] showed that corrective feedback was more effective for low English proficiency learners, but did not emerge for high English proficiency learners. It means that low English proficiency learners more needed corrective feedback. Moreover, learners with low English proficiency tend to demotivate and withdraw in English classroom activity and deprecate their ability.

Hence, the present study is designed in order to investigate the impact of OCF on the level of language anxiety by examining whether $\mathrm{OCF}$ given by the teacher has different impact to the level of LA in learners with low English proficiency during EFL classroom activity. It also explores kinds of strategy used by the learners with low English proficiency to overcome LA in EFL classroom when the teacher gives OCF. The finding of this study is expected to give valuable information to language teachers, learners and language learning professionals since none previous studies examine those issues in detail.

\section{REVIEW OF RELATED LITERATURE}

\subsection{Oral Corrective Feedback}

Corrective feedback takes the form of response to learners' utterances that contain error. The response can consist of an indication that an error has been committed, provision of the correct target language form or metalinguistic information about the nature of the error reference [5]. Further, according to reference [10] error correction implies an evident and a direct correction, whereas corrective feedback is a more general way of 
providing some clues or eliciting some corrections, besides the direct correction is made by the language teacher.

Moreover, reference [1] also stated that corrective feedback refers to any feedback provided to student that contains evidence of learner's error in any language form including oral or written, implicit or explicit. In OCF indicates corrections to repair ill forms of linguistic units used for speaking. It is given by the language teacher when the learners use incorrect target language. Meanwhile, in written corrective feedback refers to various ways in which a reader can respond to a second language writer by indicating that some usage in the writing does not conform to the norms of the target language. Moreover, implicit corrective feedback means when the language teacher interrupts students' utterance by giving some language input without metalinguistic explanation. On the other hand, explicit corrective feedback is defined when the language teacher provides the correct form through interrupt students' utterance by giving metalinguistic explanation directly.

\subsubsection{Types of Corrective Feedback}

Negative feedback also known as corrective feedback (Ammar\&Spada, 2006). It has been classified into two groups such as explicit and implicit reference [1]. According to reference [7] feedback can be explicit such as a grammatical explanation or an overt error correction, whereas implicit such as confirmation check, repetition, recast and clarification request. The example of OCF types as follows:

\section{Recast}

A recast is a reformulation of the learner's erroneous utterance and correct all or part of the learners' utterance and is embedded in the continuing discourse. The following dialogs illustrate this strategy:

\section{S: I have 20 years old. 1 \\ T: I am \\ (Partial didactic recast) \\ S: I can lend your pen?}

T: What?

S: Can I lend your pen?

T: You mean, Can I borrow your pen?

(Conversation recast)

\section{Explicit Correction}

Explicit provision of the correct form by a clear indication of an error. The correct form is provided by the instructor. Sheen (2011) indicates that phrases such as "It's not X but Y", "You should say X", "We say $X$ not $Y$ " usually accompany this treatment. Example:

S: Go post office.

T: Not 'go post office', go to the post office. We say 'I will go

to the post office tomorrow'

\section{Metalinguistic Explanation}

The correct form and a metalinguistic comment on the form are provided. It also consists of a brief metalinguistic explanation (comment, question, information) aimed at eliciting a selfcorrection from the student such as follow:

\section{$S$ : She like reading book.}

T: Third person singular. Remember? Add 's'..

S: She likes reading book.

\section{Repetition}

In order to elicit the correct form, the wrong utterance is repeated (partially or entirely). This repetition is generally accompanied by some intonation change emphasizing the error or in a question form. It also as repetition of ill-formed part uttered by a student. Example:

S: I buy a book yesterday

T: I BUY a book yesterday!

S: I bought a book yesterday

\section{Elicitation}

This strategy takes place when there is a repetition of the learners' erroneous utterance up to the point when the error occurs. Moreover, the teacher elicits the correct form from learners by using questions like "How do we say that in English?" or by asking learners to reformulate their utterances like "can you repeat". Example:

\section{S: I'll do it if I will have time \\ T: I'll do it if I .....}

\section{Clarification request}

A phrase such as 'Pardon' and 'I don't understand' following a student utterance to indirectly signal an error when the learner's utterance has an error and a clarification is requested. The teacher indicates to learners that their renditions contained some kind of errors and that a repetition or a reformulation is recommended. For instance:

S: She a student.

\section{T: What?}

\section{a. Language Anxiety}


Language anxiety is considered to be the most negative influential aspect, which prevents learners to learn a foreign language successfully. Reference [2] defined anxiety as feelings of uneasiness, self-doubt, apprehension, or worry. Further, reference [23] defined language anxiety as the feeling of tension specifically concerned with second language contexts, including speaking, listening, and learning.

\subsubsection{Types of Language Anxiety}

Anxiety, generally speaking, describes a human's worry or fear of certain objects in a setting. Specifically, there are three types of anxiety: trait, state and situation-specific anxieties reference [12]. Anxiety associated with a particular situation or context can be further categorized as either debilitating or facilitating anxiety. Further, he classified foreign language anxiety into three components as:

1. Communication apprehension

Communication apprehension arises from learners' inability to adequately express mature thoughts and ideas. It means that communication apprehension is a type of shyness characterized by fear of or anxiety about communicating with people. People who typically have trouble speaking in groups are likely to experience even greater difficulty speaking in a foreign language class where they have little control of the communicative situation and their performance is constantly monitored.

2. Fear of negative social evaluation

It arises from a learner's need to make a positive social impression on others. It also defined as apprehension about others' evaluations, avoidance of evaluative situations, and the expectation that others would evaluate oneself negatively is a third anxiety related to foreign language learning. It may occur in any social, evaluative situation such as interviewing for a job or speaking in foreign language class.

\section{Test anxiety}

It refers to an apprehension about academic evaluation. It also as a type of performance anxiety stemming from a fear of failure. Test anxiety students often put unrealistic demands on themselves and feel that anything less than a perfect test performance is a failure. Oral tests have the potential of provoking both test and oral communication anxiety simultaneously in susceptible students.

\subsubsection{Symptoms of anxiety}

The sign of anxiety based reference [23] such as in faster heartbeat, and self-belittling, muscle tension, the desire to withdraw, low verbal output and non-fluency.Further, reference [22] stated that individuals use several behaviors to soften failure and protect themselves from its overwhelming effect in order to maintain a sense of personal worth. Other symptoms suggested by reference [25] include tremors, nausea, fast pulse and shallow breathing

\subsubsection{Cause of Language Anxiety}

Reference [14] reported that, the causes of provoking test anxiety might be derived from the educational system. Language anxiety may be experienced due to linguistic difficulties foreign language learners face in learning and using the target language reference [11]. However, reference [12] claimed that foreign language anxiety is independent of first language learning disabilities and should be viewed as an important factor that hinders language learning in and of itself. The main cause of anxiety stems from learners' unrealistic or erroneous beliefs about language learning reference [30].

\section{RESEARCH METHODS}

This study used descriptive qualitative design since this research focused on a certain phenomenon in the school environment. In this case, the phenomenon was the activities in teaching and learning English. This research also did not give the treatment to the objects of the research. The subjects in this study arethe teacher of intensive English program who is active giving OCF on the students and the second semester students of intensive English program in FEBIFISIP faculty, UINSA. The students are adult learners with average age around 17 to 19 years old. A total of $(\mathrm{N}=42)$ students from two classes participate to fill FLCAS questionnaire with the number of male $(\mathrm{N}=12)$ and female $(\mathrm{N}=30)$. They will be chosen as the subject of study based on the score of FLCAS questionnaire. In order to even out the distribution of the subject, this study only takes few students $(\mathrm{N}=16)$ from each group as subject of study that will be observed and investigated deeper. As the result, 4 students are assigned to a very anxious group, 4 students are assigned to anxiety group, 4 students as mildly anxious group and 4 students are categorized as relaxed group. 


\section{FINDINGS}

\subsection{The Impact of OCF on the Level of LA}

This section describes the impact of OCF on the level of LA through observing the sign of LA from each group that occurred during speaking performance and classroom activity. To strengthen the data analysis, some possible considerations such as the psychological situation when the students from various group feel anxious, the source of language anxiety occurred during speaking performance and the impact of OCF on the level of LA are served to answer the fundamental research questions.

\subsubsection{The impact of OCF on Very Anxious Group}

The sign of language anxiety was quite clear occurred when the language teacher providedOCF. The impact of OCF on VA group learner had showed several impacts. Based on the students' response and psychological situation, the impact of OCF can be positive and negative. The negative impact such as avoidance classroom activity, poor speaking performance and selfdeprecating thought. Meanwhile, the positive impact is being propelled to study harder.

One student felt so nervous and uncomforted. She tended to be unsure and not confident to speak in English class. This is as the evident how OCF affected her speaking performance. She produced low tones, shallow breathing and had difficult to comprehend teacher's utterances.

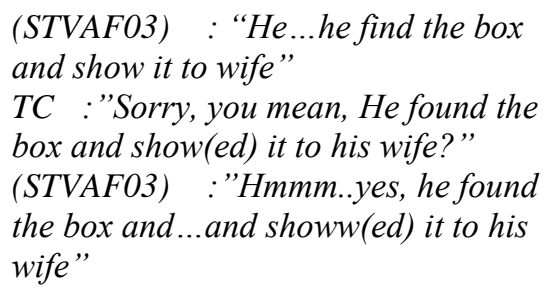

Further, she claimed that OCF made her very shy and afraid because other friends would laugh out to her. She also very anxious, tried to concern with negative social evaluation from peers. She said:

(STVAF03) :"I felt very shy because I was afraid my friends would laugh out to me if they knew my mistake. And when they laughed I felt so stress and not confident"

\subsubsection{The impact of OCF on Anxious Group}

The impact of OCF in this group was almost same. It can be classified into three categories: classroom dynamic in term of avoidance of classmate, self-deprecating thought, poor speaking performance and being propelled to work harder. The students in this group looked so lazy by often came late, postponing homework and fewer initiations of conversations and participation. Therefore, the English teacher is quite pay attention enough to the students who have a problem in communication, and participation then tried to motivate the students by giving suggestion and telling her experience to increase students' enthusiasm in English class. The teacher often asked the students in this group to speak English or participate more active during class. One of male student was asked to speak English and told his own past experience in long holiday. In his speaking performance, he said:

(STAM01): "The farmer live(d) with.... "

TC :"You must use verb 2, remembered?"

(STAM01):"'Yes..(nodded head) Hmm.The

farmer lived with the.(istri)...?

TC :" Wife"

(STAM01):"Yeees, wife.. and one

day, the farmer find a box in hefild"

TC :"Found a box in his field

(fi:ld)"

Consequently, they are uninterested in participating English class, not willing to volunteer in both asking and answering the teacher, discomfort along English class, even missing the class. The student (STAM01) expressed his feeling related to his low self-efficacy in learning English. He was questioned about his thought after the teacher provided oral correction directly. $\mathrm{He}$ replied:

(STAM01) :"I think....it is better for me to keep silent and not continue my utterance anymore, even though I feel more understand about my mistake after my teacher corrected my mistake"

\subsubsection{The impact of OCF on Mildly Anxious} Group

The findings were not same with VA and A group. The impact of OCF in MA group was not clear because the students in this group had different attitude based on their own feeling and experience. However, the impact of OCF in this group can be classified into: avoidance of advanced 
peer, self-disapproving thought, and being propelled to work harder. The students in MA grouphad different response and behavior compared to the students from other various group such as VA and A group. Female students in this group were more had positive perception about OCF's efficacy than male students did. However, generally, the students in this group nearly competed with relaxed group but still had the sign of language anxiety when the teacher provided OCF. One male student (STMAM01) produced low tones, and had difficult to convey his opinion using English. The example of his speaking performance after the teacher gave oral correction to his mistake was presented below

(STMAM01) : "Hasan my friend..."

TC :"Is.."

(STMAM01): "Ok, Hasan is my

friend..he..he is good and cheerful. He

always (menemaniapa miss)

$T C$ :"you mean accompanies"

(STMAM01) :"Yes, he always accompany me"

$T C: ”$ ,

Furthermore, the teacher tended to give OCF to the students from MA group. The students in MA group seemed not confident, because they looked so shy to their friends and also afraid of their score. It also increased their negative selfperception about their own ability in learning English. Even though, they still had confidence and enthusiast to participate in classroom activity. One of the student from mildly anxious group (STMAM02) conveyed his feeling when the teacher gave OCF on his speaking performance, while others friends from relaxed group became the audience. He was questioned whether he felt offended after the teacher corrected his mistakes in front of other friends, he said:

(STMAM02) :"Yes...hmm because it makes me not confident and decrease my enthusiast to enjoy and participate in English activity"

For some of male students in MA group, OCF increased their negative self-perception and anxious to participate English activity, but not for female students from MA group. One female (STMAF01) expressed her feeling toward OCF. When she was questioned about her feeling after her teacher corrected her mistake in front of class, she replied with unusual response. Here is the example of her opinion:
(STMAF01) :"I just accustomed because I welcome the critic and I prefer if my mistake corrected by my teacher, itmeans that my teacher pays attention to me"

\subsubsection{The impact of OCF on Relaxed Group}

Even though, most of the students in relaxed group seemed did not have any problem during participate English activity, but a particular situation also makes the students in this group rather anxious to participate English class. The psychological situation deals with the occurrence of the sign of language anxiety when they have to perform in speaking class.

One male student performed after the teacher asked him to come forward and told his past experience in long holiday. In his performance, he said:

(STRM01) : "I like to visit (tempatwisata), because..beca use. I am happy to enjoy my holiday" TC:"

Further, male student (STRM01) revealed his feeling when he joined English class. He said that he really enjoyed in participating intensive English class, he expressed that he felt so happy and enthusiast because he liked English lesson so much. He also studied English since he was in elementary school. In his utterance:

(STRM01) : "I feel so excited, because I felt... through that way...as media to evaluate and also as a prove of my governance in English skill”,

However, physically they looked so happy and enjoyed to join the whole classroom English activity but not their feeling so. The impact of OCF was really clear from their response and reaction about that. Explicitly, the student said that they were really happy when the teacher corrected their mistake during their speaking performance. However, implicitly, the students also felt uncomforted when the teacher interrupted their utterance to correct their mistake. This condition makes them avoidance inferior peer, selfquestioning cognition and also being propelled to study harder.

\section{DISCUSSION}

\subsection{The Impact of OCF on the Level of LA}

The findings show that OCF has different impact on the level of language anxiety students even tough, language anxiety associated with low 
English proficiency learners, precisely it has been experienced in learners from all levels. This study proves that English proficiency level does not determine the level of language anxiety. This finding supports Horwitz (2010: 100) and Liu (2006) arguments that although language anxiety typically occurs in learners who have low English proficiency, the fact shows all level students experience the same belief. The students in this study are from low English proficiency learners but have different level of language anxiety. The findings show the students who have the highest level of language anxiety try to demotivate themselves than the students who have the lowest level of language anxiety.

\subsubsection{The Impact of OCF on VA Group}

OCF made the students in this group more anxious, confused and tremor. They had a desire to withdraw in English class when the situation forced them speak English. Therefore, it was not effective to improve students speaking performance, especially in very anxious group who had the highest level of language anxiety in English class. The result in this study has been predicted by another researchers such as Krashen (1998), Rahimi and Dastjerdi (2012) and Ammar and Spada (2006) who had examined OCF was ineffective to increase the fluency and accuracy in speaking performance.

The finding in this study shows that the students in very anxious group (STVAF03), (STVAM01) and (STVAF02) cannot absorb the efficacy of OCF well because oral correction made them more tremor and nervous. As the result, they would forget what oral correction the teacher did to them. This finding has the same result with SLA theory Krashen (1985) who maintains OCF was not facilitate L2 learning. One male student (STVAM01) argued that OCF could improve his English knowledge because after the teacher corrected his utterance directly, he became forget easier. Thus, he could not feel the efficacy of OCF to his language achievement.

On contrary, others researchers argued that OCF precisely played an important role in language development (Ellis, 2010; Erlam, 2008; Lyster\&Ranta, 1997; Rahimi\&Zhang, 2014). Those studies supported the students' attitude and thought in this study about the effectiveness of OCF was given by teacher in their performance. Related to the efficacy of OCF, most of students (STVAF03), (STVAF02) and (STVAF1) agreed they needed oral correction to help them find their mistakes, so they could learn more through the mistake they made even though, it made them very anxious and shy.

\subsubsection{The Impact of OCF on A Group}

Feeling fidgety, tremor and nervous in speaking English in front of classmates generally are the sign of LA occurred in anxious group. However, when the teacher provided OCF on their utterance, they became more panic, and had a great desire to withdraw in joining English classroom activity. This situation also illustrated by Swain and Lapkin (1995) that OCF can be as provoking language anxiety if learners are not made aware of the purpose, and its efficacy in improving their language. Most of students believed the efficacy of OCF on their language achievement. They stated OCF given by the teacher made them learn more about their mistakes. They prefer the teacher as the only one who gave oral correction for every mistake they did. This opinion is maintained by Kaivanpanah (2012) that the most favorite choice of correctors in anxious learners is the teacher as the primary source of knowledge and the expertise in teaching and learning process.

Students (STAM01), (STAF01) and (STAF02) agreed that OCF could enrich their knowledge and improve their pronunciation. This belief has been claimed by Carroll (1995), Ellis (2009), Zhang and Rahimi (2014), and Erlam (2008) that learner's mistakes facilitate them to notice the differences between their incorrect utterance and the target form, as a consequence improving to L2 development. Nevertheless, student (STAM02) could not feel the effectiveness of OCF, because he just felt anxious when he spoke English spontaneously and did not understand what the teacher said to him, so he could not absorb the knowledge of oral correction well even it hinder him to speak fluency. Riasati (2011), Christenberry (2001), Kim (2000) and Elkhafaifi (2005) supported this finding from the revelation of their study. Their students also had the same experience concerned with listening skill. They agreed that listening was the most difficult thing in learning English after speaking, because the existence of different intonation and the lack of vocabularies made them very difficult to comprehend the point what the interlocutor was saying.

\subsubsection{The Impact of OCF on MA Group}

The students in MA group have different response and perspective toward OCF. It was 
caused by the situation where they felt LA after the teacher gave oral correction and the sources of language anxiety really determined their attitude about the efficacy of OCF. This finding is quite similar to the research conducted by Dehbozorgi (2012) that there is no significant relationship founded between learners' attitudes of L2 learning, and language proficiency. However, the result of this study shows students' attitude of L2 learning, and language proficiency level have no significant connection, but have significant relationship between OCF, students' attitude and the level of language anxiety. However, there have been a considerable number of researches by Gomleksiz (2010), Oller, Hudson and Liu (1977) that investigated there were close relationship between students' attitude and L2 learning.

Some female students (STMAF01), (STMAF02) felt they had learned more after the teacher gave OCF but some male students (STMAM01), (STMAF02) not. The result shows that male undergraduate students in this group are more anxious, while female undergraduate students look more relaxed and have positive reaction on the efficacy of OCF. This runs have the similar result with Yan and Horwitz's (2008) study who also concerned with the investigation whether gender influence students' attitude and emotion in participating English classroom activity. The findings show female students (STMAF01), (STMAF02) prefer if the teacher should correct their mistakes because they needed OCF to detect their mistake that they were unconscious with that. However, male students (STMAM01), (STMAF02) claimed that in a particular situation, OCF prevented them to speak English fluently. As a consequence, it impedes students' enthusiast to speak more and longer in front of class. On contrary, many other researchers Batumlu and Erden (2007), and Dewaele (2007) also found that there was not any relationship between language anxiety and different gender.

\subsubsection{The Impact of OCF on R Group}

OCF also influenced students in $\mathrm{R}$ group when they had to discuss with other inferior students. The effectiveness of OCF, precisely impede the students to speak confidently because they were very concerned to make a mistake in front of other inferior students. The situation where the students felt uncomforted even dislikes in cooperative learning was more likely to feel anxious. This argument is supported by Onwuegbuzie (1999), Duxbury and Tsai (2010) that find the more frequently group work take place, the more the students feel anxious. By contrast, Liu (2006) maintains that the learners from different level of class mostly feel less anxious when they work in a group discussion.

OCF also contributes on the LA in a particular situation. It could be caused by many factors such as peer unpleasant behavior, comparison with classmates and learner habit. Therefore, this study shows there are close relationship between OCF, comparison with classmates, and students' unpleasant behavior. The findings show that the more students compared their ability with inferior learners, the more OCF became ineffective. The students in this study have different response with the study conducted by $\mathrm{Su}$ (2010) and Liu (2008) who reported that groping students was beneficial to decrease language anxiety and increase self-confident. In fact, the R students precisely try to avoid inferior learners because they were afraid about failure and negative judgment from inferior peers.

Moreover, the highest desire to achieve the successful learning will make them to force themselves to always show the best performance both in a group discussion and in speaking performance. Similarly, with Gregersen and Horwitz (2002) that found fear of getting unsatisfied score or failure caused language anxiety. On other words, OCF cannot contribute a great positive impact when the students felt anxious too much to be best. Generally, the result showed that OCF tended to give positive rather than negative impact. The students in $\mathrm{R}$ group felt anxious just after the teacher gave OCF to their mistake in front of other groups, but after that, they looked so enthusiast to improve their speaking performance by preparing the material before join English class. In line with the study conducted by Keshavarz (2003), and Vahdatinejad (2008) studies that OCF can facilitate to determine what the learners needs to be mastered and taught.

\section{CONCLUSION}

Basedon the findings and discussion, it can be concluded that OCF has different impact to the level of LA. OCF given by the teacher to the students from very anxious and anxious group is more debilitated rather than facilitated. It depends on the students' attitude about the efficacy of OCF on their language achievements. The students in 
very anxious and anxious group have negative reaction to OCF since the practice prevents students' creativity to produce more output in speaking performance. It also makes the students from those groups much more anxious, tremor, easy to forget every word they have prepared and confused when the teacher interrupted their utterance.

However, the different impact has been experienced by the students in mildly anxious and relaxed group. The impact of OCF on mildly anxious group is not quite clear since the learners have different response and reaction to its efficacy.

\section{REFERENCES}

[1] Ammar, A., \&Spada, N. 2006. One size fits all? Recasts, prompts and L2 learning. Studies in Second Language Acquisition, 28, 543-574.

[2] Brown, H. D. 2001. Teaching by Principle and Interactive Approach to Language Pedagogy. New York: Pearson Education.

[3] Dewaele, J. M. and Thirtle, H. 2009. Why do Some Young Learners Drop Foreign Languages? A Focus on Learner-internal Variables. International Journal of Bilingual Education and Bilingualism 12 (6), 635649.

[4] Elkhafaifi, H. 2005. Listening Comprehension and Anxiety in the Arabic Language Classroom. The Modern Language Journal, 89(2), 206-220. Retrieved $28 \quad$ April 2017 from http://onlinelibrary.wiley.com/doi/10.1111/j.1540 4781.2005.00275.x/abstract

[5] Ellis, R. 2006. Researching the effects of formfocused instruction on L2 acquisition. AILA Review: Themes in SLA Research, 19, 18-41.

[6] Ellis, R. 2009. Corrective feedback and teacher development. L2 Journal 1, 3 e 18.

[7] Ellis, R., Basturkmen, H., \&Lowen, S. 2001. Learner uptake in communicative ESL lessons. Language Learning, 51(2), 281-318.

[8] Erlam, R. 2006. Elicited imitation as a measure of L2 implicit knowledge: An empirical validation study. Applied Linguistics, 27, $464-491$.

[9] Gregersen, T. S., \& E.K. Horwitz. 2002. Language learning and perfectionism: Anxious and nonanxious language learners' reactions to their own oral performance. The Modern Language Journal $86.4,562-570.4$.

[10] Han, Z. H. 2008. Error correction: Towards a differential approach. Paper presented at The Fourth QCC Colloquium on Second Language Acquisition. New York, NY. Retrieved from http://www.tc.columbia.edu/academics/?facid=zhh2

[11] Hashemi M, Abbasi, M. 2013. The role of the teacher in alleviating anxiety in language classes. Int. Res. J. Appl. Basic Sci. 4(3):640-646.

[12] Horwitz, E. 2001. Language anxiety and achievement. Annual Review of Applied Linguistics, 21, 112-126.

[13] Horwitz, E. K. 2008. Becoming a Language Teacher: A Practical Guide to Second Language Learning and Teaching. USA: Pearson Education, Inc.

[14] Huang, HW. 2005. The relationship between learning motivation and speaking anxiety among EFL non-English major freshman in Taiwan. M.A.
Some of them argued that OCF increased their enthusiast because it also enlarged their feeling afraid of negative reaction peers if they made a lot of mistakes. Nevertheless, other students agreed that it has many benefits to help students recognize their mistakes during in speaking performance. The same feeling also experienced by students in relaxed group who have a great positive response about the efficacy of OCF. They felt so happy and satisfied when the teacher corrected their utterance contained linguistic error, so they could learn through their mistakes.
Thesis, Unpublished. Taiwan: Taichung, Chaoyang University of Technology.

[15] Jang, Sung-Soo. 2011. Corrective feedback and language anxiety in $L 2$ processing and achievement. English Teaching, 66(2), 73-99.

[16] Keshavarz, M. D. 2003. Error Analysis and Contrastive Analysis. Error Analysis in Translation and Learner Translation Corpora. In Mitchell, R. and Myles, M. 2004. Second language learning theories. New York: Hodder Arnold.

[17] Kim, J. H. 2000. Foreign Language Listening Anxiety: A Study of Korean Students Learning English. Unpublished Doctoral Dissertation, University of Texas at Austin.

[18] Liu, M. 2006. Anxiety in Chinese EFL students at different proficiency levels. System, 34(3), 301-316.

[19] Liu, M. 2008. Reticence and anxiety in oral English lessons. Bern: Peter Lang AG.

[20] Liu, K. L. 2012. College EFL Teacher' Perspectives of English Language Anxiety and Self-perceived Teacher Roles in Managing College Students' Language Anxiety. Journal of National Formosa University 30 (3), 53-66

[21] Lyster, R., Saito, K., \& Sato, M. 2013. Oral corrective feedback in second language classrooms. Language Teaching, 46(01), 1-40.

[22] Merritt, L., Richards, A., \& Davis, P. 2001. Performance anxiety: Loss of the spoken edge. Journal of Voice, 15(2), 257-269.

[23] Mitchell, R., \& Myles, M. F. 2004. Second language learning theories. London: Hodder Arnold.

[24] Rahimi, A., \&Dastjerdi, H., V. 2012. Impact of immediate and delayed error correction on EFL learners' oral production: CAF. Mediterranean Journal of Social Sciences, 3(1), 45-54.

[25] Rachman, S. 2004. Anxiety (2nd ed.). New York: Taylor \& Francis.

[26] Ranta, L., \&Lyster, R. 2007. A cognitive approach to improving immersion students' oral language abilities: The Awareness-Practice-Feedback sequence. In R. DeKeyser (Ed.), Practice in a second language: Perspectives from applied linguistics and cognitive psychology (141 - 160). New York: Cambridge University Press.

[27] Riasati, M. J. 2011. Language Learning Anxiety from EFL Learners' Perspective. Middle-East Journal of Scientific Research, 7(6), 907-914.

[28] Saville-Troike, M. 2006. Social contexts of Second Language Acquisition. Introducing Second Language Acquisition. Cambridge University Press, pp. 99-132.

[29] Vahdatinejad, S. 2008. Students' Error Analysis and Attitude towards Teacher Feedback Using a Selected 
Software: a case study. Unpublished Masters Thesis. University of Kebangsaan Malaysia, Bangi.

[30]

Zhang R, Zhong J. 2012. The hindrance of doubt: Causes of language anxiety. Int. J. English Linguist. 2(3):27-33. doi:10.5539/ijel.v2n3p27. 